\title{
John David Scott, 4th June 1936 in Godalming Surrey to 10th January 2013 in Llangattock Powes
}

Eye (2013) 27, 577-578; doi:10.1038/eye.2013.33; published online 1 March 2013

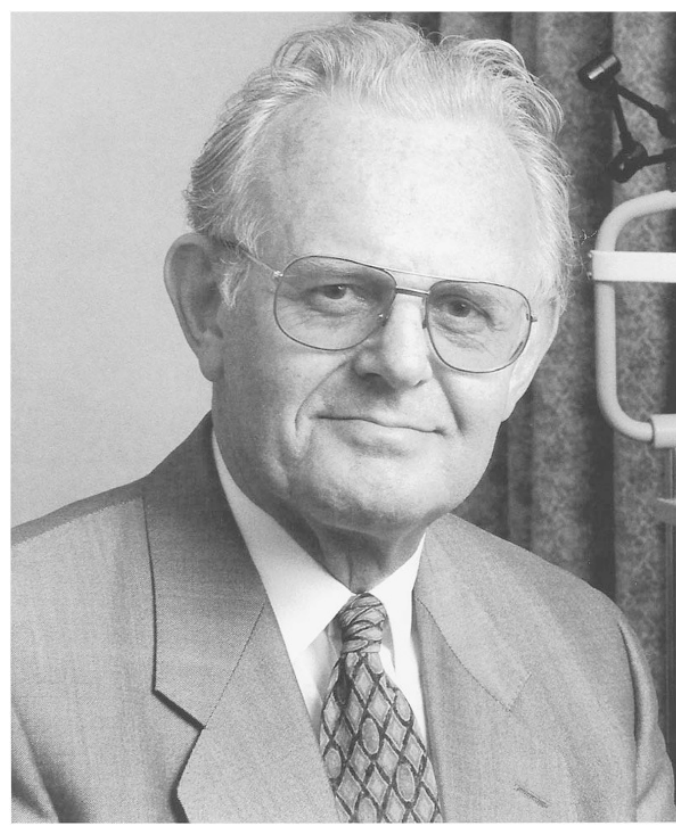

It is a tragic irony that within a few months of being given an Honorary Fellowship of the Royal College of Ophthalmologists in recognition of his extraordinary contribution to the clinical management and science of retinal detachment, John Scott should be struck down by an aggressive cancer.

John was the product of a strict and intense upbringing. The strictness made him indulge in many pursuits. His natural ability made him good at all of them and the intensity made him a perfectionist. By the time he came to medical school at St Mary's Hospital in Paddington, London, he was not only an excellent scholar but also a highly competent violinist; a great asset to the hospital orchestra.

As with all medical students of that era the study of medicine only occupied a proportion of his time. John used this extra freedom with a
P Watson

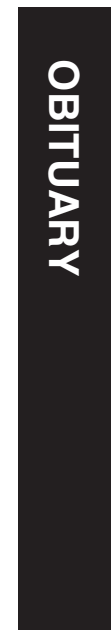

friend to become a clockmaker, an interest he pursued for the rest of his life. He also supported himself by volunteering for clinical experiments and helping in a workshop in Praed St mixing glues and repairing violins. At this time, intelligent student pranks were not only expected but tolerated by all. The most effective of these was the organization of a contra-flow traffic diversion around St Mary's hospital with no exits.

In keeping with his character, but to the surprise of his peers as he appeared to be doing no work, John passed his exams at the very top of the table and was given the coveted medical house physician appointment to Professor Peart; the leading physician of his day.

John became interested in ophthalmology while doing his surgical residency and returned to St Mary's to start his training in the subject. He worked with Gregory Keith, the senior registrar in the department who was interested in the diagnosis and treatment of retinal detachment. It was he who enthused John and, true to form, he wholeheartedly took on the challenge of finding a cure for this condition, which at that time had an appalling prognosis.

He completed his training at Moorfields Eye Hospital, where his original ideas were accepted by some but not by all. Nevertheless, his obvious expertise, interest, and forward thinking about the causes and possible therapies for the various forms of retinal detachment led him to become a protégé of Mr Lorimer Fison, who recommended him to be appointed to Addenbrooke's Hospital in Cambridge in 1967 at the age of 31 years.

A condition of his appointment was that he spent time in the United States of America with those who were advancing the treatment of retinal problems there. He spent time with Ed Norton in Miami, Harvey Lincoff in New York, and Ed Okun in Missouri. It was here 
where he was able to examine the patients who had been operated upon by Paul Cibis, who had died at the very young age of 40 years. Cibis had developed the first vitreous cutter and had used silicone oil to repair some very difficult detachments. John was so impressed by what he saw that he brought all the unused stock of silicone oil back to Cambridge so that he could develop its use.

This pioneering work did not receive universal approbation and opposition to its use in Boston, USA, led to the failure of silicone oil to be approved by the FDA long after it was in routine use for severe retinal problems in Europe and the Far East.

Progress was rapid. Within 2 years he had described and published the first report on 'open skies' vitrectomy for the late complications of diabetic retinopathy and previously failed detachment surgery. Despite facing fierce criticism from some quarters, John's abilities, intellect and integrity gradually won over a growing band of supporters in the United Kingdom and abroad. He described and published the results of 'open skies' vitrectomy for the late complications of diabetic retinopathy Giant Retinal tears, and particularly those occurring in children and young adults with Stickler's syndrome attracted his attention. He developed special delaminating scissors and he had a rotating Striker operating table constructed to which the anaesthetized patient was strapped. John lay on a mechanic's trolley under the patient so allowing gravity to unfold the collapsed retina.

Retinal detachment 50 years ago was a universally blinding disease. As a consequence of John's pioneering work in the most intractable forms of this condition, retinal detachment is now, almost always treatable, with good visual results in most people.

Soon after his return to Cambridge, the Royal Commonwealth Society for the Blind (now Sight Savers International) offered John the opportunity to work in Enugu in SE Nigeria, caring for patients after the Biafran War. Treating his patients required the minor detail of first re-building the operating theatre at the hospital to which he was attached and travelling to many villages with his driver to examine patients, those deemed treatable being brought back to hospital for surgery.
While there he developed viral encephalitis, which he treated with locally brewed 'Star' beer, and when he was well enough he would be carried to his clinics on a chair. He received the Duke elder medal from the Royal College of Ophthalmologists, the Charamis Medal from the European Society of Ophthalmologists, and was the first UK opthalmologist to be awarded the Herman Wacker Prize from the Club Jules Gonin, but the honour which pleased him most was that he was made an honorary Chief by the community he served. Occasionally, on a late Sunday evening ward round, he would mischievously use his tribal title when introducing himself to patients arriving from the African continent.

Considering the amount of work involved and his dedication to his specialty with its out of hours commitment and his teaching sessions which brought many from the surrounding area and from London, it is amazing that he ever had time for anything else. He did have and did everything to the full. From childhood he developed an amazing ability to isolate his many activities from each other, whether this be with family, sailing first in dinghies and then progressing to larger sailing boats and finally a beautiful old wooden motor vessel, Astrovolante, in Majorca, racing motor cars, collecting vintage ones, being an advanced driving instructor, being fluent in a new language, or flying planes and gliders. Every one of these activities gathered a group of friends and enthusiasts. He would take on each tasks until he felt he was totally competent and then moved to another. Music beat him in this struggle for perfection and, although he was a superb violinist and viola player, with his knowledge of classical music he knew that there was always somewhere else to go. When I saw him last, his major regret was that he had no longer the strength to play.

We were close colleagues and friends for nearly 50 years. In the whole of that time including a sailing holiday with very little wind, we never had any disagreement. All problems, whether professional or otherwise, could be solved with a glass of good claret and a comfortable chair by the fire. He was a great surgeon and a great companion. 